This item was submitted to Loughborough's Research Repository by the author.

Items in Figshare are protected by copyright, with all rights reserved, unless otherwise indicated.

\title{
Kropotkin's theory of the state: a transnational approach
}

PLEASE CITE THE PUBLISHED VERSION

http://www.routledge.com/books/details/9781138797208/

\section{PUBLISHER}

Routledge

VERSION

AM (Accepted Manuscript)

\section{PUBLISHER STATEMENT}

This work is made available according to the conditions of the Creative Commons Attribution-NonCommercialNoDerivatives 4.0 International (CC BY-NC-ND 4.0) licence. Full details of this licence are available at: https://creativecommons.org/licenses/by-nc-nd/4.0/

\section{LICENCE}

CC BY-NC-ND 4.0

\section{REPOSITORY RECORD}

Kinna, Ruth. 2019. "Kropotkin's Theory of the State: A Transnational Approach". figshare. https://hdl.handle.net/2134/16625. 


\section{Kropotkin's theory of the state: a transnational approach}

\section{Ruth Kinna ${ }^{1}$}

This chapter examines Kropotkin's sociology of the state. It outlines his analysis of the modern European state's emergence in order to illuminate the transnational dimension of his thinking. Kropotkin presents a powerful critique of imposed uniformity and injustice in the context of an appreciation of linguistic and cultural diversity, or national difference. He establishes the artificiality of state organisation, which he associates with a particular principle of sovereignty, to highlight the fluid nature of state boundaries and the anarchistic and disintegrative forces that had the potential, sadly unrealised, to challenge the extension of statism in Europe. Kropotkin's argument, that transnationalism has the potential to undermine or reinforce statist principles helps explain his fears about the spread of European militarism, Prussian Caesarism and his apparently paradoxical stance on the war in 1914.

\section{Introduction: Transnationalism}

Transnationalism, Steven Vertovec argues, is a slippery concept. Broadly referring 'to multiple ties and interactions linking people or institutions across the borders of nationstates', the range of phenomena that it describes is a matter of some debate. ${ }^{2}$ The origins of the concept can be traced to the early twentieth century. In an essay entitled 'Transnational America' published in 1916, Randolph Bourne developed the idea through a critique of 'Americanization' and of the myth of the 'melting pot' that the 1914-18 war had dramatically exposed. America, he argued, expounded universal principles but was in fact characterised by the persistence of particularism. America's constituent cultural groups 
were steeped in a highly romanticised idea of old-fashioned European patriotism, which had been stripped of any real sense of community obligation and were assimilated through the promise of freedom, fortune and the conquest of 'material resources'. The result was intolerance and the emergence of a vapid, commercial culture based on competitive advantage. Transnationality, as Bourne understood it, provided a counter to these destructive forces and described the prospect of a new libertarian, democratic culture underpinned by universal principles. Identifying as trans-nationals, Bourne thought, Americans would be able to transcend the ways of the old world and commit to new 'social goals' based on 'the good life of personality lived in the environment of the Beloved Community'. ${ }^{3}$

Bourne's understanding might be characterised as centripetal: his concern was to show how particularist currents could be pulled towards the state's central axis. In contrast, contemporary literatures tend to cast transnationalism as a centrifugal force, pulling across and sometimes against states. The six strands that Vertovec identifies within it describe processes of social formation which intensify global relationships (despite the existence of legal, regulatory, cultural borders); the development of structures and systems supporting these relationships, both legal and illegal networks; the creation of global public spaces, virtual or otherwise; the emergence of vehicles and mechanisms supporting global capital flows, particularly transnational corporations; complex patterns of cultural interpenetration, both corporate and grass-roots; and the expression of subversive, anti-hegemonic and antiessential discourses and practices. ${ }^{4}$

As Bamyeh observes, in its modern application transnationalism presupposes the very divisions that anarchist political theory disputes: it takes the boundaries of the state as given, 
typically bypassing the strong historical parallels that exist between transnational transmissions and pre-modern, 'even ancient "world systems"'. ${ }^{5}$ Kropotkin shared this view. As an anti-statist, Kropotkin contested the statist idea that the emergence of European states marked the foundation of political societies. For him, the state represented the degenerative transformation of pre-existing political organisations. And his aim was to expose the state's artificiality by treating fluidity and movement as a sociological norm. On this account, processes of interpenetration and permeability could be read as measures of anarchistic well-being or as indicators of the success of statist principles of solidity and fixity. Only in the former sense, however, would transnationalism provide long-term stability. In the state system, it created instability. Kropotkin's interest in the fate of the Russian Empire made him acutely sensitive to the tension between the tendency towards state territorialisation, on the one hand, and globalisation, on the other. The general conclusion of his analysis was that in the state system transnationalism bred nationalism and rivalry for the control of resources, threatening violence on a global scale.

In recent anarchist histories transnationalism has provided the springboard to study the networks, movements, communication flows and shared practices that nineteenthcentury activists created and engaged with, particularly as a result exile and forced migration - the processes that Vertovec highlights. The bonds of solidarity that Bourne attached to the concept are also central to these studies, but attached to anarchist diasporas rather than the nation-state. As Constance Bantman argues, pre-war anarchist and syndicalist movements were transnational to the extent that they were prime movers in the development of a 'practical and integrated' international labour movement. ${ }^{6}$ From this perspective, the problem that transnationalism confronts is the tension between the 
enduring pull of national loyalty and the principled commitment to international ideals. And the greatest disappointment for the anarchist movement remains the apparent betrayal of these ideals by leading activists like Kropotkin.

Kropotkin's position contained significant tensions and one of the upshots of his analysis was that internationalism, understood as a principle of worker solidarity, only offered a partial solution to the global violence that the state system supported because it was predicated on the acceptance of organisational principles that anarchism disputed. Kropotkin also argued that it was impossible to think about submerging differences between cultural and language groups. Like Bourne, Kropotkin was interested in the centripetal aspect of transnationalism, but whereas Bourne searched for a principle capable of transcending nationality, Kropotkin embraced national variation, finding the social glue that Bourne sought in citizenship in anarchist ethics and revolutionary discourses and practices. As he noted in his memoirs, there was an intimate relationship between the institutional and ethical aspects of his work. Referring to the process of completing Mutual Aid, he wrote:

These researches which I had to make during these studies in order to acquaint myself with the institutions of the barbarian period and with those of the mediaeval free cities, led me to another important research - the part played in history by the State, since its last incarnation in Europe, during the last three centuries. And on the other side, the study of the mutual support institutions at different stages of civilization, led me to examine the evolutionist bases of the sense of justice and of morality in man. $^{7}$

Kropotkin's critique of the state pointed to the existence of trans-historical and crosscultural practices which contained the potential for a new kind of cosmopolitan community, 
one which extended beyond the 'melting pot' that Bourne felt too thin to bind groups and individuals, without either sacrificing the principle of particularity or defaulting to an aspiration for material conquest. His analysis does not suggest that the disintegrative forces that challenged imperial regimes promised anarchy. Indeed, in the years leading up to the First World War he became increasingly concerned that the fragility of the international state system heralded increasing militarisation. Nevertheless, his understanding of transnationalism illustrates the distinctively anarchist character of his aspiration for fluidity and diversity in social organisation and by revealing its theoretical ground, helps explain his willingness to support the Allied campaign.

To begin, I discuss Kropotkin's account of the rise of the modern European state from the sixteenth century, and with particular reference to the development of the Russian empire, and then consider the implications of his historical sociology for his understanding of state organisation, function and resistance. At the end of the essay, I consider the limits of Kropotkin's internationalism and his stance on the First War.

\section{The Rise of the Modern European State}

In the entry for anarchism published in the Encyclopaedia Britannica in 1905, Kropotkin describes the state as a body which seeks to restrain the complex, dynamic movements of social forces. The harmony it achieves - which is hardly harmonious - results from an artificial restriction of social movements, reliant on force and repression. In contrast, a society without the state represents 'nothing immutable'. Kropotkin continues: 
On the contrary - as is seen in organic life at large - harmony would ... result from an eververy-changing adjustment and readjustment of equilibrium between the multitudes of forces and influences, and this adjustment would be the easier to obtain as none of the forces would enjoy a special protection from the State. ${ }^{8}$

There are strong echoes of Proudhon in Kropotkin's formulation, but he made it his own by deploying analogies from atomic physics. ${ }^{9}$ Turning to European history, Kropotkin linked the emergence of the modern state to the decline of the city states in the fifteenth century and the collapse of the complex network of co-operative, guild and mercantile organisations which supported them. This analysis did not presume uniformity in the internal social arrangements of pre-state societies, though he noted that popular, selfgoverning organisational forms were remarkably similar, whatever the sociological context. For example, Kropotkin noted that the artel, a 'prominent feature of Russian life since the dawn of history' and 'a spontaneous outgrowth of popular life', looked very much like later West European co-operative societies, even though it emerged without self-conscious ethical reflection. ${ }^{10}$ Yet whatever the local variations, the point was that all forms of grass roots organising were threatened by the state and that its success might be measured by the speed and completeness of their disappearance. The decline of the guilds in Western Europe was a particularly strong indicator of this sociological and ethical shift and, in common with modern historians, Kropotkin argued that it was during this period that the term 'state' first came into use to define a particular political arrangement. ${ }^{11}$ 
Implicitly rejecting the inevitability of the state's rise, Kropotkin looked for factors explaining its success in the failings of the city-states, placing coercion at the heart of his explanation. ${ }^{12}$ There were, he argued, three main reasons for the city-states' decline. First was the division of the city population from the village communities. The inability or unwillingness of the cities to liberate the peasantry from their feudal overlords not only meant that the latter retained their economic power base but also that the cities themselves became over-reliant on commerce and industry. Second was the failure of the cities to prevent the rise of inequalities within their walls. Whilst feudal barons skilfully infiltrated the cities, the commercial success of groups within them helped create divisions between rich and poor. The resulting economic inequalities gave rise to social instability which the barons, jealous of the cities' wealth, were able to exploit. ${ }^{13}$ The last, and in Kropotkin's view, most important failing was the cities' inability to embed its own principles and ideals. Always vulnerable to competing principles and wrestling with political disruption, the cities fell victim to the appeal of a statist political idea, which Kropotkin associated with authority, divinity and law. In some of his earliest essays, he had identified the trinity of economic, military and religious elites as the primary forces behind the state and, in terms reminiscent of Rousseau, explained its rise as a consequence of popular gullibility. ${ }^{14}$

Naturally, there were particular circumstances which helped explain the increasing purchase of the state. In Russia, Kropotkin linked the decline of popular democracy and the rise of elitism to a geopolitical contest between Novgorod and Moscow and the ability of Moscovites to court the favour of Mongol invaders through intrigue and bribery. ${ }^{15}$ In Mutual Aid, however, he returned to the generic processes and stressed the ideational conditioning that bolstered the statism: 
The students of Roman law and the prelates of the Church ... had succeeded in paralyzing the idea - the antique Greek idea - which presided at the foundation of the cities. For two or three hundred years they taught from the pulpit, the University chair, and the judges' bench, that salvation must be sought for in strongly-centralized State, placed under a semi-divine authority; that one man can and must be the saviour of society, and that in the name of public salvation he can commit any violence ... ${ }^{16}$

Kropotkin linked the idea of the state to absolutism, epitomised in monarchical rule, but he did not identify its uniqueness with the principle of sovereignty, as early state theorists contended. Rather, he thought that the rise of the state involved the reinterpretation of the principle in the context of political centralisation. Sovereignty, he argued, ultimately devolved to individuals. It was the principle that captured the 'free play for the individual' and the idea that 'no actions are imposed upon the individual by fear of punishment'. ${ }^{17}$ Keen to distinguish this position from the ideas advanced by some liberals and individualist anarchists, notably Benjamin Tucker, Kropotkin denied that sovereignty was adequately described as an abstract right or a claim against others, and instead argued that it operated only within a social context. ${ }^{18}$ Defined in this manner, sovereignty underwrote the agreements that individuals entered into in their social relations, and it was therefore compatible with the cooperative principle of mutual aid, with which Kropotkin coupled it. In the medieval cities, these agreements supported the jurisdictional claims of the cities' institutions. Like the modern states that succeeded them, each city-state 'had the 
right of war and peace, of federation and alliance with its neighbours. It was sovereign in its own affairs, and mixed with no others. ${ }^{19}$ The difference was that, in the medieval context, sovereignty was never defined by the law-making power of a single body, be it a monarch or a parliament. This was his point of disagreement with Hobbes and Bodin. For the latter:

... a ship is no more than a load of timber unless there is a keel to hold together the ribs, the prow, the poop and the tiller. Similarly, the commonwealth without sovereign power to unite all its several members, whether families, colleges or corporate bodies, is not a true commonwealth. It is neither the town or its inhabitants that makes a city state, but their union under a sovereign ruler, even if they are only three households. Just as the mouse is as much numbered among animals as the elephant, so the rightly ordered government of only three households, provided they are subject to a sovereign authority, is just as much a commonwealth as a great empire. ${ }^{20}$

In Kropotkin's view, this argument was a philosophical conceit. Returning to history he outlined the process that lay behind it:

the State must perforce annihilate cities based on direct union between citizens. It must abolish all union within the city, abolish the city itself, abolish all direct union between cities. To the federative principle it must substitute the principle of submission and discipline. Submission is its substance. Without this principle it leaves off being the State; it becomes a federation. ${ }^{21}$

Throwing out the formal-legal doctrine established in the Treaty of Westphalia Kropotkin argued that in practice sovereignty was divisible. Even if the 'supreme political 
power' was 'vested entirely in a democratic forum ... ', ${ }^{22}$ within the city sovereignty was shared: the guilds and communes that composed it had their own jurisdictions, for example, they assumed 'communal responsibility' for crime, they organised their own decisionmaking forums, militias, religious houses and enterprises. In sum, each city was a double federation of 'households united into small territorial unions - the street, the parish, the section - and of individuals united by oath into guilds according to their professions' ${ }^{23}$

Kropotkin's account of the city-states enabled him to distinguish sovereignty as a principle of 'self-jurisdiction' and 'self-administration' from a hierarchical principle of command. In the former, individuals agreed to give up some of their powers, but they retained their sovereignty, the guarantee of freedom. In the latter, on the Hobbesian account at least, (and its Social Darwinian incarnation was one of Kropotkin's important targets) individuals were right bearers, but never sovereign, and in the process of creating sovereignty, they renounced their rights, or their liberty, and made their effective power conditional on the will of another.

An important implication of this casting was that the concept of the state could be applied to a range of organisational forms, for example, both nation-states and empires. The distinguishing marker was the principle of submission. Kropotkin traced the effects of the transformation of sovereignty in different sociological contexts by examining changes in social relations, processes of territorialisation and inter-state relations.

Looking at the social relations that the city state and the modern state variously fostered he argued that the modern sovereign state 'does not recognize a freely adopted union working within itself. It only deals with subjects. The State and its prop, the Church, arrogate to themselves alone the right of being the connecting link between men'. ${ }^{24}$ In the 
modern era, Kropotkin observed, the vertical domination of social relations threatened to make even the Church redundant. His prediction, which Rudolf Rocker subsequently endorsed, was that the doctrine of political obligation was destined to subsume all other moral commitments and that the state would assume an ethical role. ${ }^{25}$

Even morality, which for centuries has preached obedience to the Church or to some so-called divine book, emancipates itself to-day only to preach servility to the State. "You have no direct moral obligation towards your neighbour, nor even a sentiment of solidarity; all your obligations are to the State" we are taught by this new religious of the old Roman and Caesarian divinity. Neighbours, comrades, companions - forget them! You must know them only through the intermediary of an organ of your State. ${ }^{26}$

In the eighteenth-century, Kropotkin argued, law began to replace religion as the medium through which European states exercised their moral power. Yet the establishment of the rule of law, greeted by liberals and even some revolutionaries as a counter to the arbitrariness of monarchical rule, marked only the beginning of a new system of regulation, as corrosive to trust and civility as the old ordinances of the Church. Unlike contemporary anarchist theorists, Kropotkin did not discuss regimes of domination, but his analysis suggested the inadequacy of thinking that power was vested exclusively in the instruments of the state. The shift in sovereignty had significant repercussions for the conduct of ordinary human interactions. Civility gave way to servility and the effect was felt in habitual bullying and persecution. Consider, Kropotkin argued, 'what corruption, what depravity of mind is kept up among men by the idea of obedience, the very essence of law; of 
chastisement; of authority having the right to punish, to judge irrespective of our conscience and the esteem of our friends ...' ${ }^{27}$

Turning to territorialisation, Kropotkin's second area of concern, he again outlined a transformative process, emphasising the corrupting influence of the state on social organisation. The 'concept of a common territory', he argued, emerged in the pre-Christian times, with the appearance of village communities and the shift from tribal union. ${ }^{28}$ Both the principle and the social form could be found across the world, in Europe, Africa and Central and South America, though the organic nature of village life meant that there could be no 'absolute uniformity' in organisation. ${ }^{29}$ Kropotkin acknowledged the exclusivity of territorialism: territory supported the formation of nation groups. Yet he defined nations as 'nothing else ${ }^{30}$ but language communities. Even though he admitted that groups typically adopted leadership structures, he argued that these arrangements were consensual. Moreover, although he sometimes elided nation with race, he downplayed the idea of shared history and instead emphasised the common practices that territorialism fostered. In village communities it gave rise to customs, institutions and habits that supported cooperation, leading to confederation and cross-cultural exchanges. Kropotkin observed the spontaneous formation of countless 'scientific, literary, artistic and educational societies' in the city rather than the village community. ${ }^{31}$ But insofar as cities were spaces for the expression of the same principles of mutual aid and also brought together individuals from different national groups, they attested to the compatibility of territorialism and transnationalism. Kropotkin's important claim, that 'the conception of nations' developed 'long before anything like a State has grown in any part of the continent', supported an ethnographic analysis. ${ }^{32}$ Consequently, whereas Bourne understood nations as displaced 
subject-groups and cast transnationalism as the solution to the loss of meaningful communal bonds, Kropotkin predicated transnationalism on the existence of consensual, national communities and the absence of citizenship and formal democratic structures. ${ }^{33}$

With the emergence of state sovereignty, territorialisation served as a platform for colonisation and cultural homogenisation. As historians of modern Europe have shown, a number of phenomena supported these processes: publishing, urbanisation and the development of Universities all played a role. Kropotkin's story focused on the 'wholesale massacres' legal restrictions, land appropriation, taxation and absentee landordlism designed to bring village life under the domination of the state. ${ }^{34}$ In relating it, one of his central concerns was to show how colonisation brought nationalism into particularly sharp focus. Russia provided a case study.

In Russia, colonisation had proceeded more slowly in the Empire than in most West European states and its effects were obvious because of the diversity of its national groups. Kropotkin's list included 'Finnish-speaking and Swedish-speaking Protestants ... Germanspeaking, Lett-speaking and Esth-speaking Lutherans ... Polish-speaking Roman Catholics and Yiddish-speaking Jews ... Tartar-speaking Mahommedians. Even 'European Russia ... contains a great variety of nationalities, languages and religions' and 'in the Caucasus there is a conglomeration of races and languages such as is to be found on no other portion of the earth's surface'. ${ }^{35}$ Colonisation began the early and mid-nineteenth century under Nicholas I and Alexander II. ${ }^{36}$ With the accession of Alexander III it was accelerated in an aggressive policy of Russification, felt by imposition of 'the language, religion and administrative institutions of the dominant race'. Not un-coincidentally, the three 'great principles of Nationality, [Eastern] Orthodoxy, and Autocracy' resulted in a marked increase in anti- 
Semitism. The policy proceeded in waves and the later 'manifestation of nationalism' in the period of the third Duma (1907-1912), directed against the 'de-nationalizing forces' of the 'heterodox races under Russian rule' reinforced Kropotkin's sense that statism was equally active on representative forms of government, not just Tsarism. Anarchy was the alternative and describing anarchists and nihilists as exponents of the anti-statist cosmopolitan principle, he set himself against nationalism but supported the heterodoxy that ethnography implied. ${ }^{37}$

Kropotkin's discussion of inter-state relations, the third area in which he examined the impact of the state's claim to sovereignty, explored the contradictions and limits of statism. His starting point was that the state's colonising efforts were only partially successful and that the relationships which extended beyond the state's regulatory control intensified in the modern era. The reasons were partly connected with the arbitrariness of territorial borders, which never reflected historical migratory movements and consequently never mapped precisely to the subsequent development of nations. Russia illustrated the problem very well: meeting the potentially disintegrative pressures exerted by national groups within the state's borders not only tested the efficiency of the state's repressive machinery, it also bound it to policies that played out externally. Specifically, Russification committed Tsarist authorities to offer protection to Slavs in the Ottoman Empire and, because of the commercial interests that Western states had in the trade routes under Turkish control, it mired Russia in years of diplomatic intrigue and war. ${ }^{38}$ In the other part, the uncontainable power of political ideology exposed states to critical assessment. Kropotkin pointed to the egalitarian ideals unleashed by the French revolution, undiminished by the 1815 European settlement, to make the point. ${ }^{39}$ His argument was not 
that revolutionary principles were necessarily coupled with anti-statist claims (even Catherine the Great had dabbled with the ideas of the philosophes), ${ }^{40}$ only that the currents of ideas circulating in the post-revolutionary period, which sometimes dovetailed with nationalist aspirations, also had the potential to direct the centrifugal tendencies active in existing states towards anarchy, and that the twin forces of nationalism and radicalism helped explain both the antagonisms of the inter-state relations and its inherent fragility.

Kropotkin's account of the state's emergence helped him clarify that its dominant characteristics were distortions or perversions of established practices and not unique or novel features. Like the state, the city state was regulated by particular sets of rules. The law, Kropotkin argued, 'originated in established usage and custom' and represented 'a skilful mixture of social habits, necessary to the preservation of the human race, with other customs imposed by those who used popular superstitions as well as the right of the strongest for their own advantage' ${ }^{41}$ Yet in the cities, the jurisdictions were overlapping and the claims to sovereignty were never fixed. Similarly, the cities, in common with village communities, developed forms of self-government. Neither resembled state government because both emerged from the engagement of local people or national groups, supporting systems of decision-making that were decentralised and federal.

Kropotkin's acknowledgement of the state's parasitic relationship with the forms of political organisation that preceded it is important because it suggests that his understanding of the state's abolition did not imply the necessity of total destruction and utopian rebirth, as is sometimes claimed in contemporary anarchist critique, but instead a change of practices. The re-modelling of the mir in Russia after the emancipation was an example of the kind of transformative action that Kropotkin had in mind. Kropotkin's story 
of the state also clarified the role for anarchist ethics. The city states, he argued, provided spaces for individuals to collectively build institutions that expressed their shared moral rules: from fair trading to charitable giving. Yet they did not remove social tensions, and nor could they. Nevertheless, the nationalist aspirations that statism catalysed pointed to a very different set of possibilities. It was the ambition of the state, through its direct mediation of all social relations, to impose uniformity and compliance. The city states facilitated a much more complex social structure and they succeeded precisely because they gave free reign to local conflicts that direct communal relationships involved. Whereas the state was characterised by immobility and the quality of social life depended on the extent to which it could keep a lid on conflicts, the city state was defined by movement. Struggle, Kropotkin argued, was 'the guarantee of free life in a free city'. The morality of the city states was measured by '[c]onflict freely thrashed out, without an external power, the State, throwing its immense weight into the balance, in favour of one of the struggling forces'. ${ }^{42}$ Open disagreement and even violence were indicators of change: it was the 'spirit of routine, originating in superstition, indolence, and cowardice' that was 'the mainstay of oppression'. Kropotkin certainly understood how the struggles of different ethnic and religious peoples might result in new forms of oppression. His response was to fight for a dynamic condition, limiting the possibilities of domination by resisting the institutionalisation of power. When he considered the possibility of anarchist transformation Kropotkin did not, therefore, anticipate the achievement of perpetual peace, but the development of a politics that was always open to contestation, mediated by the complex interrelationship of national groups and transnational global networks. Because of the ways in which the state had developed, 
the success this anarchic ideal depended on the realisation of communism. Kropotkin's recommendation was derived from his analysis the state's function.

\section{The State: Function and Resistance}

Like Max Weber, Kropotkin placed monopoly at the heart of his definition of the state, but whereas Weber treated monopoly as an organisational feature of the state, associating it with the legitimate use of physical force in a given territory, Kropotkin identified monopoly as its function. Modern states, he argued, of course claimed a monopoly in the 'defence of the territory', but their purpose was to serve as instruments 'for establishing monopolies in favour of the ruling minorities'. In the modern European state, the fulfilment of this role permitted 'the few to monopolize the land, and the capitalists to appropriate for themselves a quite disproportionate share of the yearly accumulated surplus of production'. All states, both ancient and modern, served the same purpose. ${ }^{43}$ And monopolies were not only established in branches of industry and production, but also, for example, in education, religion and transport. Indeed, monopoly extended even to morality, backed by law.

The State is an institution which was developed for the very purpose of establishing monopolies in favour of the slave and serf owners, the landed proprietors, canonic and laic, and merchant guilds and money-lenders, the kings, the military commanders, the noblemen, and finally, in the nineteenth century, the industrial capitalist, whom the State supplied with "hands" driven away from the land. ${ }^{44}$ 
Kropotkin's language chimed with radical thinking. Like many radicals, he believed that the tendency of the state was towards the extension of directly-controlled monopolies. Anticipating this development, he argued that the expansion of the state's management functions into 'all social organization including the production and distribution of wealth' threatened to create a new 'form of autocracy', every bit as illiberal as the absolutism that was established on the back of the city states and notwithstanding the increasingly frequent use of the discourse of democracy to legitimate it. ${ }^{45}$ However, his parallel critique of capitalism distanced him from those radicals and liberals who argued that the solution to monopoly lay in the free market and mutual recognition of individual rights. ${ }^{46}$

Whether it took a public or private form, monopoly was inextricably linked to capitalism and to patterns of ownership, principles of production and systems of international trade that structured social divisions within states and created inequalities between them. ${ }^{47}$ In this respect, Kropotkin's ideas resembled Hobson's and Lenin's. Yet because he did not focus his understanding of monopoly on the formation of business cartels or the concentration of the unregulated financial power that drove imperialism, he did not share Hobson's euchronian hopes for the perfection of the market economy and international governance. ${ }^{48}$ Similarly, unlike Lenin, whose thought dovetailed with Hobson's, Kropotkin rejected the idea that monopoly described a shift in capitalism which shaped state behaviours and had the potential to transform global political and social relations. ${ }^{49}$ Accordingly, Tom Mann recommended 'a good course of Peter Kropotkin' to enlighten those who believed that the 'realisation of the Collectivist State' was 'equal to the realisation of the revolutionary ideal'.$^{50}$ Monopoly was a broad sociological tendency that encompassed all areas of social, political and economic life. For example, as global shifts in economic 
power (resulting from changes in patterns of trade, the successful exploitation of new markets, technological development or, as in the case of Germany, state-sponsorship of industry) altered the relative advantage of elites located within particular territories, the state's internally monopolistic form heightened the competitive pressures between states. From this perspective monopoly was part of a dynamic inter-state relationship, driven by economic rivalries, prestige or 'the honour of kings', ${ }^{51}$ stimulating increasingly aggressive competition. ${ }^{52}$ To complete the picture, Kropotkin argued that monopoly was underwritten by an international financial system which left all states in hock to bankers but ensured that some states, those who best served the interests of financial elites, occupied the strongest position in the international realm. ${ }^{53}$ The dependency of states on banks and the interdependencies that this relationship bred belied the claims to sovereignty that state-s advanced, yet the political fiction remained intact, bolstered by the spread of nationalistic sentiments. Kropotkin estimated that 'four-fifths of French savings' were 'poured into' one of five great banks and that organisations from 'foreign States ... railway companies, towns, or industrial companies from the five continents of the globe' were reliant upon them. The profits that the banks made on their loans were enormous, and the machinery at their disposal to 'boom them' was unrivalled. ${ }^{54}$ Consistent with his other histories, Kropotkin tracked the origins of international finance back to the collapse of the city states.

Towards the end of the Middle Ages most of the large Republican cities of Italy ended by running up huge debts. When the period of decay of these cities had begun, owing to their continued endeavours to conquer rich Oriental markets, and the conquest of such markets had caused endless ward between the 
Republican cities themselves, they began to contract immense debts to their own rich Merchant Guilds. A like phenomenon is to be seen now in modern

States, to which syndicates of bankers are willing to lend against a mortgage on their borrowers' future income. ${ }^{55}$

Kropotkin's final reflection on monopoly was that it was unstable. Ordinary miscalculations on the returns of particular capitalist ventures resulted in spectacular economic collapse. Yet as monopolistic states relied on evermore extensive and sophisticated weaponry to fulfil their domestic function and production was diverted to military purposes, investment decisions were increasingly linked to the anticipation of wars and the expectation of their economic outcomes. Like Weber, then, Kropotkin argued that the monopoly of violence was a characteristic of the state and that there was an inverse relationship between legitimate exercise of domestic violence and the deployment of external force. At the same time, Kropotkin's contention that monopoly was enmeshed in markets weakened the significance of the territorial dimension of Weber's definition, blurring the distinction between the state's internal and external aspects. For Kropotkin, both were expressions of the complexity of capitalist inter-state relations.

Given the enormity and inter-connectedness of the issues that Kropotkin identified in his analysis of the state, it would be easy to conclude that resistance was futile and that annihilation was a more likely result of social change. Indeed the answer he gave to the question he posed at the end of The State: Its Historic Role - 'Will it produce death?' - was: 'It will, unless we reconstitute society on a libertarian and anti-State basis'. ${ }^{56}$ Kropotkin's hope was that individuals could be encouraged to regain their initiative, think and act for themselves and shed the habits of 'submission and discipline ${ }^{157}$ inculcated by the state. By 
taking back the powers that they had theoretically alienated in the process of the state's formation, they would rebuild their local relationships and rescue or re-shape their institutions as they saw fit. Fuelled by moments of high optimism, notably in 1905, Kropotkin never quite gave up hope that a popular anti-state movement would assert itself in direct action, but his underlying fear was that tide of change, at least in the West, was against the anarchists. The tension in his thought is evident in the ideas he explored in a letter to Max Nettlau in 1912:

The State phasis which we are traversing now seems to be unavoidable, but whatever its duration may be, it will never reach now the State Socialist conditions which were once imagined once upon a time by the social democratic and the Vidal school. Before they should come to that, there would be accomplished a complete change in the very forms of modern industrial production. I believe that, so far as we may see forward at this moment, it would be good tactics to help the Labour Unions to enter into a temporary possession of the industrial concerns, under the conditions of delivery at certain established prices their products to given regions of consumers. This would be perhaps an effective means to check the State Nationalisation. ${ }^{58}$

Kropotkin's commitment to direct action was a central tenet of his anarchism, intimately linked to his critique of the state. An important corollary was that action should be directed towards the rejection of monopoly. In The Conquest of Bread and Fields, Factories and Workshops, it became apparent that Kropotkin thought about this issue both in terms of the logistical problems raised by resistance as well with reference to the exposition of alternative, non-statist principles of organisation. His conclusion was that 
these were two aspects of the same issue. In contemporary language, his approach was prefigurative: Kropotkin identified an intimate link between the means and ends of social transformation and also believed that alternatives could be foreshadowed in present actions. His understanding of the state's function convinced him that the issues anarchists faced were not just about how to organise production, distribution and exchange in the abstract, but more concretely, how to do so in ways that would result in alternatives that were capable of withstanding the tendency to monopoly and, insofar as was possible, insulated against the inequalities that monopoly promoted. On the one hand, this conviction encouraged theoretical inflexibility. For example, in contrast to anarchists like Benjamin Tucker, whose rights-based anarchy opened 'the way for reconstituting under the heading of "defence" all the functions of the State ${ }^{159}$ Kropotkin argued for the necessity of the abolition of private property and the wages system and the abandonment of international trade as well as the adoption of decentralised federalism. On the other hand, his involvement in actual struggle left him open to compromise. In 1895 he admitted that he had no more 'faith in Trade Unions, as such, than in political action'. However, he continued: 'we prefer those unionists who rely upon their own action to those who cry for State help. Our propaganda might usefully deal with this question'. ${ }^{60}$ Both positions pointed to a particular politics, namely anarcho-communism and to the possibility of building a strong anti-statist, transnational communities.

\section{Anti-statism, anarchism and the war}

Kropotkin's critique of the state illuminated the permeability of territorial boundaries and the potential for disintegration - anarchy in the sense of chaos. His concern to resist 
monopoly pointed towards a form of anarchism that had a distinctive ideological gloss and which painted a resilient form of anarchy as order. The relationship between these two forces was dynamic, uncertain and potentially dangerous and in the years leading up to 1914, Kropotkin assessment of it vacillated.

What sort of community did Kropotkin have in mind? His interest in the rise of the modern European state perhaps suggests that his thinking was Eurocentric and that he prioritised those movements that set themselves against nineteenth-century states over those which preceded them and/or emerged in the non-European world. Kropotkin's claim, in Mutual Aid, that the anarchist principle achieved its greatest, albeit imperfect, and most self-conscious expression in the European medieval city states ${ }^{61}$ suggested the historical and geographical origins anarchism could be located precisely. Kropotkin's advocacy of anarchist-communism similarly indicates that his community was defined by rigid ideological commitment. As an exponent of anarcho-communism and a critic of Tucker, Kropotkin helped create a storm within the anarchist movement which caused some Spanish anarchists, and later Voltairine de Cleyre, to declare for 'anarchism without adjectives'. Kropotkin argued that anarchism was not a dogma but in opposition to these alternatives he was firm in his belief that it entailed a commitment to anarcho-communism.

Both these views are partial. Kropotkin's critique of the state opened up a gap between anarchist practices, which were not defined by resistance to the European state, and anarchist politics, advanced as a counter to monopoly. This gap is also apparent in his definition of anarchism. The historical account of anarchism points to an extraordinarily broad tradition, encompassing ancient Chinese and Greek thought, and his political advocacy indicates a much narrower conception, focused on the creation of the First 
International. Kropotkin's description of the double character of anarchism in the entry for the Encyclopaedia was not original. Ernst Zenker's 1897 critical study of anarchism, described by James Martin as 'the first study of a general nature which showed an understanding of the scope of the source material of anarchism', ${ }^{62}$ linked the spirit of anarchism with a number of Reformation and pre-French Revolutionary movements, but nevertheless identified Proudhon as the father of the doctrine. ${ }^{63}$ In the former guise, anarchism was merely a 'modernised versions of the Chiliasts' and not 'so very original'. In Proudhon's hands, in contrast, it brought together a socialist demand for the abolition of property with the principle of 'Federalism and free association'. ${ }^{64}$ Kropotkin's treatment was naturally far more positive and whereas Zenker used the association with popular movements ('vagabonds' and 'robbers') ${ }^{65}$ to illustrate anarchism's dangerous criminality, Kropotkin used it to highlight the existence of a positive, energetic trans-historical and transnational movement. Moreover, rather than assuming an identity with European aspirations, he showed how ideas, customs and behaviours resonated with the politics of the movement which explicitly self-identified as anarchist. Membership of the transnational community was derived from the expression of anti-statist sentiments. Why was the Stoic Zeno of Crete an exponent of anarchist philosophy? Kropotkin's answer was that he 'repudiated the omnipotence of the State, its intervention and regimentation, and proclaimed the sovereignty of the moral law of the individual'. ${ }^{66}$

When Kropotkin considered the practicalities of building transnational community, he advocated a politics shaped by the rejection of monopoly. Distinguishing anarchist practices from anarchist politics, Kropotkin hoped that the disintegrative or de-nationalising forces active in states might open the way for anarchist transformation. It became clear in 
the course of 1914-18 that his faith in the possibility of transnational community was misplaced and that nationalist sentiments, also nurtured by the instability of the state system, overwhelmed it. Nevertheless, Kropotkin's decision to support the Allied war effort against Germany followed from this calculation. Although his support for the Allies in 1914 shocked many of his former comrades, others found Kropotkin's decision less puzzling. One commentator commented that Russian socialists like Kropotkin did not support the Allies 'from any Pan Slavism (they see the danger and menace of such a frame of mind only too well), but because they are convinced that Prussian militarism must be defeated, and because of their faith in the Liberalising forces in Russia herself'. ${ }^{67}$ Russia's instability encouraged Kropotkin to think that there was a potential for anti-statist action which, in the context of the state system, had the potential to ignite similarly anarchic forces across Europe.

Russia was central to Kropotkin's reasoning, but his well-publicised view that Prussian militarism 'is a more formidable menace to freedom than even Russian Czarism', reflected his assessment of the development of statism in Europe, rather than a concealed nationalist sentiment. ${ }^{68}$ Kropotkin was hardly blind to the evils of Russian autocracy. For years he had spearheaded international campaigns to draw attention to the most repressive aspects of Tsarist rule and explain the revolutionary violence that the regime provoked. Kropotkin's book, The Terror in Russia, one reader noted, 'enables us to see why a Stolypin meets his death'. ${ }^{69}$ Kropotkin's analysis of the state, fleshed out in a critique of German monopoly, on the one hand, and an assessment of the relative weakness of Russian statism, on the other, convinced him that the reassertion of transnational over statist principles demanded resistance to German expansion. As he explained: 
All the nationalities which have hitherto been oppressed by the larger nationalities, when they are free to develop their own lines of thought, art, and political growth, will most certainly bring into the common treasury of the world their own most precious features, which they cannot show so long as they are oppressed by a bigger nationality.

The same $[\mathrm{sic}]$ for the South Slavs and for all nationalities oppressed in Europe. When the last Balkan War had shown the inner power of the South Slavs, I greeted in it the disintegration of the three other Empires - Austria, Russia, and

Comment $[\mathbf{B C D}(\boldsymbol{\& L} \mathbf{5}]$ : Check in citation that the original sentence has no verb either?

Comment [R6]: Yes, added the indicator

Formatted: Font: Italic

His optimistic view was that the war - itself a result of the instability of the state system - would provide a break on the extension of monopoly in Russia and support the development of anti-state federation. 'From the beginning of the war' he argued, 'the Unions of the Zemstvos ... and the Municipalities were accomplishing wonders in caring for the wounded ... and in supplying the Army with all sorts of necessities, including medical appliances, boots, tents, baths, and so on'. ${ }^{71}$ In a similar vein, noting the appalling conditions that war imposed, Kropotkin told one correspondent that 'all classes ... conquer the rights' by 'taking part in the life of the country' and 'by practising these rights'. This was a reassertion of individual sovereignty and he 
detected echoes of the French Revolution in the action. Just as the sections of Paris had imposed 'their will in political and economical matters, simply by taking into their own hands' the sale of Church lands so, too, in Russia were 'peasants and intellectuals alike' contributing to the 'efforts to live through this calamity'. ${ }^{72}$

The defeat of Germany did not, of course, pave the way for the realisation of Kropotkin's transnational ideal but it did expose the gap between a principle based on the transcendence of national difference, rooted in class solidarity (with or without regard to anti-statist organisation), and his rather different transnational vision, which rooted solidarities in cultural difference.

\footnotetext{
${ }^{1}$ I am extremely grateful to Alex Prichard for his insightful comments and, above all, to Bert Altena and Constance Bantman for pressing the arguments and providing invaluable support and encouragement during the drafting of this paper. Thanks also to David Struthers for encouragement at an early stage of its development.

2 Steven Vertovec,'Conceiving and researching transnationalism', Ethnic and Racial Studies, 22.2 (1999) pp. 449-455. [447-462].

${ }^{3}$ Randolph Bourne, 'Trans-National America', Atlantic Monthly, 118 (July 1916), 86-87. http://www.swarthmore.edu/SocSci/rbannis1/AlH19th/Bourne.html [last access 10.1.14].

${ }^{4}$ Vertovec,'Conceiving and researching transnationalism', pp. 449-455.

${ }^{5}$ Mohammed Bamyeh, 'Introduction', Current Sociology (1993), 41: 31, p. 1.

${ }^{6}$ Constance Bantman, The French Anarchists in London, 1880-1914. Exile and Transnationalism in the First Globalisation (Liverpool: Liverpool University Press, 2013), p. 8.

${ }^{7}$ Kropotkin, Memoirs of a Revolutionist (London: Folio, 1978), pp. 336-7.

${ }^{8}$ Peter Kropotkin, 'Anarchism', in R. Baldwin (ed.) Kropotkin's Revolutionary Pamphlets (New York: Dover, 1970), p. 284.

${ }^{9}$ Peter Kropotkin, 'Anarchism: Its Philosophy and Ideal', in Baldwin, pp. 115-22.

${ }^{10}$ Donald Mackenzie Wallace, Peter Kropotkin, C. Mijatovich and J.D Bourchier, A Short History of Russia and The Balkan States, Reproduced from the $11^{\text {th }}$ edition of the Encyclopaedia Britannica, (London: Britannica Company Ltd., 1914), p. 24.

${ }^{11}$ Quentin Skinner argues that the term 'state' was used to describe an independent political apparatus in the fifteenth century. Foundations of Modern Political Thought vol. 2 (Cambridge: Cambridge University Press, 1978), p. 353. See also Skinner 'The State' in T. Ball, J. Farr \& R. Hanson (eds.) Political Innovation and Conceptual Change, (Cambridge: Cambridge University Press, 1995), pp. 90-131.

${ }^{12}$ For a modern analysis of the role of coercion in the development of the European state system see C. Tilly Coercion, Capital and European States, AD 990-1992 (Oxford: Blackwell, 1995).

${ }^{13}$ Kropotkin, Mutual Aid: A Factor of Evolution, (Boston: Extending Horizons Books, n.d.), pp. 219-220.

${ }^{14}$ Peter Kropotkin, 'Law and Authority', in Baldwin, p. 205.

${ }^{15}$ Wallace, Kropotkin, Mijatovich and Bourchier, A Short History of Russia and The Balkan States, p. 44.

${ }^{16}$ Kropotkin, Mutual Aid, p. 220.

${ }^{17}$ Peter Kropotkin, 'Modern Science and Anarchism', p. 157.
} 


\footnotetext{
${ }^{18}$ See Kropotkin, 'Modern Science and Anarchism', p. 173. Kropotkin distinguishes the rights-based claims of individualists like Herbert Spencer and Benjamin Tucker from the Hegelian, metaphysical individualism of Stirner, pp. 161; 173.

${ }^{19}$ Kropotkin, Mutual Aid, p. 179.

${ }^{20}$ Jean Bodin, Six Books of the Commonwealth, *** bk. 1. chap. 2-5.

${ }^{21}$ Peter Kropotkin, The State: Its Historic Role, (London: Freedom Press, 1943), p. 31.

${ }^{22}$ Kropotkin, Mutual Aid, p. 179.

${ }^{23}$ Kropotkin, Mutual Aid, p. 181.

${ }^{24}$ Kropotkin, The State: Its Historic Role, p. 31.

${ }^{25}$ Rocker, Nationalism and Culture trans. Ray E. Chase, (Minnesota: Michael E. Coughlin), 1978.

${ }^{26}$ Kropotkin, The State: Its Historic Role, p. 41.

${ }^{27}$ Kropotkin, 'Law and Authority', p. 217

${ }^{28}$ Peter Kropotkin, Mutual Aid, p. 120.

${ }^{29}$ Kropotkin, Mutual Aid, p. 123.

${ }^{30}$ Kropotkin, Mutual Aid, p. 137.

${ }^{31}$ Kropotkin, Mutual Aid, p. 261.

${ }^{32}$ Kropotkin, Mutual Aid, p. 136

${ }^{33}$ Kropotkin, Mutual Aid, p. 262.

${ }^{34}$ Kropotkin, Mutual Aid, p. 225; 224-236.

${ }^{35}$ Wallace, Kropotkin, Mijatovich and Bourchier, A Short History of Russia and The Balkan States, pp. 69-70.

${ }^{36}$ Wallace, Kropotkin, Mijatovich and Bourchier, A Short History of Russia and The Balkan States p. 70.

${ }^{37}$ Wallace, Kropotkin, Mijatovich and Bourchier, A Short History of Russia and The Balkan States pp. $69 ; 78$.

${ }^{38}$ Wallace, Kropotkin, Mijatovich and Bourchier, A Short History of Russia and The Balkan States pp. 59-60; 64.

${ }^{39}$ Wallace, Kropotkin, Mijatovich and Bourchier, A Short History of Russia and The Balkan States p. 63.

${ }^{40}$ Wallace, Kropotkin, Mijatovich and Bourchier, A Short History of Russia and The Balkan States p. 58.

${ }^{41}$ Kropotkin, 'Law and Authority', in Baldwin (ed.) p. 206.

${ }^{42}$ Kropotkin, The State: Its Historic Role, p. 24.

${ }^{43}$ Kropotkin referred to the Macedonian and Roman empires as examples of early states. 'Anarchism', p. 286.

${ }^{44}$ Kropotkin, 'Modern Science and Anarchism', p. 166.

${ }^{45}$ Kropotkin, 'Anarchist Communism', in Baldwin, p. 50.

${ }^{46}$ On the state and capitalism see Kropotkin, 'Modern Science and Anarchism', p. 181.

${ }^{47}$ Kropotkin, 'Anarchist Communism', p. 48.

${ }^{48}$ Peter Cain, Hobson and Imperialism: Radicalism, New Liberalism, and Finance 1887-1938, (Oxford: Oxford University Press, 2002, p. 240. 'Euchronians' are future orientated political dreamers who trust that individuals are able to use reason, science and technology to fashion ideal societies. See also pp. 168-9; 103-4.

${ }^{49}$ Cain, p. 158.

50 'Tom Mann Writes from the Mid-Atlantic', Maoriland Worker 4 (138) 26 September 1913, p. 3. http://paperspast.natlib.govt.nz/cgi-bin/paperspast?a=d\&d=MW19130926.2.16 [last access 10.1.14].

${ }^{51}$ Kropotkin, Wars and Capitalism, (London: Freedom Press, 1914), p. 3.

52 Kropotkin, Wars and Capitalism, p. 3.

${ }^{53}$ Kropotkin notes: 'it was not the skill of the directors of these companies that created their lucrative position. It was the State ... in the first place, that protected and favoured these banks, and raised them to a privileged position which soon became a colossal monopoly'. Wars and Capitalism, p. 9.

${ }^{54}$ Kropotkin, Wars and Capitalism, p. 9.

${ }^{55}$ Kropoktin, Wars and Capitalism, p. 7.

${ }^{56}$ Kropotkin, The State: Its Historic Role, p. 44.

${ }^{57}$ Kropotkin, The State: Its Historic Role, p. 31.

${ }^{58}$ Kropotkin to Nettlau, March 12 1912, Nettlau Papers, Correspondence, Kropotkin, 728, International Institute of Social History, Amsterdam.

${ }^{59}$ Kropotkin, 'Anarchism', p. 297.

${ }^{60}$ Notes by Kropotkin on the back of p. 17 and 22 of a manuscript in English c. 1895, Nettlau Papers, Correspondence, Kropotkin, Petr. A. 1892-1913, 725, International Institute of Social History, Amsterdam.

${ }^{61}$ Peter Kropotkin, Mutual Aid, p. 186
} 


\footnotetext{
62 James J. Martin 'Bibliographical Essay' Men Against the State: The Expositors of Individualist Anarchism in America, 1827-1908, p. 281 online at https://mises.org/books/Men_Against_The_State_Martin.pdf [last access 10.1.14].

${ }^{63}$ Ernst Victor Zenker, Anarchism; a Criticism and an History of the Anarchist Theory, (New York and London: The Knickerbocker Press, 1897), Bibliolife facsimile edn.

${ }^{64}$ Zenker, pp. 310; 318. Once he had stripped it of what he considered to be its utopian features and impractical assumptions, Zenker concluded that anarchism was best described as a method of liberalism which lacked a distinctive 'dogma'.

${ }^{65}$ Zenker, p. 308.

${ }^{66}$ Kropotkin, 'Anarchism', p. 288.

67 'Socialists and Peace. Reply to the "N.Z. Times". An Ill-informed Paper's Misstatements Corrected', Maoriland Worker, 27 Janurary 1915, p. 4. http://paperspast.natlib.govt.nz/cgibin/paperspast?a=d\&d=MW19150127.2.39 [last access 10.1.14].

${ }^{68}$ J.T. Paul, 'Industrial World. News and Notes', Otago Daily Times, 21 November 1914, p. 14.

http://paperspast.natlib.govt.nz/cgi-bin/paperspast?a=d\&d=ODT19141121\&e [last access 10.1.14].

69 'The Editorial "T". Something About Terrorism', Maoriland Worker, 6 October 1911, p. 4.

http://paperspast.natlib.govt.nz/cgi-bin/paperspast?a=d\&d=MW19111006.2.8.4 [last access 10.1.14].

70 'Prince Kropotkin and Europe', Dominion 22 February 1915, p. 7 (quoting a letter from Kropotkin to R.J. Kelly, published in the Manchester Guardian). http://paperspast.natlib.govt.nz/cgibin/paperspast?a=d\&d=DOM19150222.2.39 [last access 10.1.14]

71 'The New Regime in Russia. Famous Exile Interviewed', Dominion, 24 May 1917, p. 5. http://paperspast.natlib.govt.nz/cgi-bin/paperspast?a=d\&d=DOM19170524.2.28\&e [last access 10.1.14].

${ }^{72}$ Copy by Nettlau of a letter by Kropotkin relating to the translation of Paroles d'un Révolté, partly in shorthand, n.d. Nettlau Papers, Documents on Kropotkin, Correspondence, 2706, International Institute for Social History, Amsterdam.
} 